\title{
EFEKTIVITAS PENGGUNAAN KREDIT USAHA TERHADAP PRODUKTIVITAS UKM DAN PENDAPATAN UKM ANGGOTA KOPERASI DI KELURAHAN PADANGSAMBIAN, KECAMATAN DENPASAR BARAT, PROVINSI BALI
}

\author{
I Wayan Chandra Adyatma* dan Made Dwi Harmana \\ Program Diploma IV Akuntansi Perpajakan, Sekolah Vokasi Universitas Warmadewa, Denpasar- \\ Bali, Indonesia \\ *e-mail: chandraadyatma8@gmail.com
}

\begin{abstract}
The purpose of this research is to determine the effectiveness of credits on the SMEs productivity and the income of cooperative members' SMEs in Padangsambian Village. The analytical tool that used on this research is the SEM analysis of Partial Least Square (PLS). This study uses primary data conducted by distributing questionnaires to SMEs that borrow business loans on the Padangsambian Village as many as 100 respondents. The results of the research analysis test show (i) The effectiveness of the use of business credit has a positive and significant effect on the productivity of SMEs in Padangsambian Village. (ii) Productivity of SMEs has a positive and significant effect on the income of SMEs in Padangsambian Village. (iii) The effectiveness of the use of SME business credit in Padangsambian Village has a positive and significant effect on the income of SMEs in Padangsambian Village through the productivity of the UKM.
\end{abstract}

Keywords: Effectiveness, Productivity, SME, Credit, Cooperatives

\section{PENDAHULUAN}

UKM merupakan sektor yang memiliki daya tahan tinggi saat krisis, sektor UKM tidak terpengaruh keadaan ekonomi pada tahun 1998, hal ini karena modal produksi untuk UKM tergolong rendah dan padat karya. Dalam sebuah penelitian yang dilakukan oleh Adi (2018), tingkat daya saing diukur melalui indeks skor antara 1,0 (daya saing paling rendah) dan 10,0 (daya saing paling tinggi) yang dikembangkan berdasarkan sejumlah faktor termasuk diantaranya jenis teknologi yang digunakan, metode produksi yang diterapkan, jenis produk yang dibuat, dan semuanya itu mengandung satu unsur penting, yaitu modal.

Peranan modal sangat penting bagi pertumbuhan sektor usaha kecil dan menengah, modal memiliki peran yang besar dalam hal pemenuhan infrastruktur, biaya operasional, dan tenaga kerja (Kurniawan, 2011). Penelitian yang dilakukan oleh Putra (2013) menyebutkan bahwa segi permodalan UKM dibagi menjadi 4 yaitu milik sendiri, keluarga, pinjaman perorangan, dan lembaga keuangan perbankan. Dilihat dari kontribusi pinjaman yang mampu di berikan kepada masyarakat, bank dan lembaga keuangan merupakan lembaga yang 
paling layak, karena perputaran uang yang tinggi mampu mensejahterakan masyarakat yang menjadi debitur maupun kreditur dalam lembaga tersebut.

Provinsi Bali merupakan salah satu wilayah di Indonesia, yang sebagian besar penduduknya bermata pencaharian sebagai petani, sektor jasa dan perdagangan. Bali merupakan salah satu pulau yang memiliki jumlah UKM terbesar ketiga di Indonesia setelah Jawa dan Sumatera (BI, 2015). Terdapat beberapa usaha-usaha yang dikembangkan oleh pengusaha untuk membuka lapangan pekerjaan dan menyediakan fasilitas untuk para wisatawan internasional maupun domestik.
Kota Denpasar merupakan kota yang berada di Provinsi Bali, sebagian besar warganya banyak berkecimpung dalam dunia bisnis UKM dari data yang diperoleh di Dinas Koperasi, UKM dan Perisdustrian Kota Denpasar terdapat 32.685 unit industri UKM. Banyaknya pelaku Usaha Kecil, dan Menengah (UKM) di Kota Denpasar merupakan aset tersendiri yang akan memperkuat pondasi perekonomian daerah. Peran UKM adalah untuk dapat membantu mewujudkan pertumbuhan ekonomi, pemerataan, dan peningkatan pendapatan masyarakat, penciptaan lapangan kerja, dan pengentasan kemiskinan.

Tabel 1

Jumlah UKM per tahun di Kota Denpasar

\begin{tabular}{cccccc}
\hline No & Nama Kecamatan & 2016 & 2017 & 2018 & 2019 \\
\hline 1 & Denpasar Utara & 9.573 & 11.260 & 10.045 & 10.727 \\
2 & Denpasar Barat & 792 & 11.212 & 11.804 & 11.605 \\
3 & Denpasar Selatan & 204 & 6.147 & 6.812 & 5.251 \\
4 & Denpasar Timur & 526 & 2.142 & 2.182 & 3.243 \\
\hline & Total & 11.905 & 30.761 & 30.843 & 31.826 \\
\hline
\end{tabular}

Sumber: Dinas koperasi usaha mikro kecil dan menengah kota Denpasar Tahun 2019 (data diolah)

Adapun jumlah UKM yang ada di Kota Denpasar seperti dijelaskan di Tabel 1 diatas, Kecamatan Denpasar Barat memiliki jumlah UKM yang paling tinggi dibandingkan dengan kecamatan lainnya. Kecamatan Denpasar Barat peneliti pilih sebagai lokasi penelitian didasari dengan alasan bahwa Daerah Padangsambian memiliki banyak sekali usaha kecil dan menengah yang didominasi oleh toko kelontong, fashion, kuliner, dan sejenisnya yang mampu memberikan pekerjaan bagi yang tidak memiliki pekerjaan.

Koperasi adalah wadah perekonomian bagi masyarakat yang sesuai dengan kepribadian bangsa Indonesia, didasari dengan asas gotong royong dan kekeluargaan, Koperasi diharapkan semakin berkembang untuk dapat meningkatkan kesejahteraan masyarakat di 
Indonesia. Apabila kita lihat kegiatan kewirausahaan tidak lepas dari modal dan kredit, dari Tabel 2 kita dapat lihat data jumlah koperasi di wilayah Kecamatan Denpasar Barat, antara lain:

\section{Tabel 2}

Jumlah koperasi simpan pinjam di Kecamatan Denpasar Barat 2019

\begin{tabular}{lcc}
\hline No & Nama Kelurahan & Jumlah \\
\hline 1 & Padangsambian klod & 5 \\
2 & Pemecutan klod & 15 \\
3 & Dauh puri kauh & 9 \\
4 & Dauh puri klod & 3 \\
5 & Dauh puri & 2 \\
6 & Dauh puri kangin & - \\
7 & Pemecutan & 4 \\
8 & Tegal harum & 6 \\
9 & Tegal kerta & 6 \\
10 & Padangsambian & 21 \\
11 & Padangsambian kaja & 11 \\
\hline
\end{tabular}

Sumber: Badan pusat statistika kota Denpasar Tahun 2019

Menurut Artis (2012) kenyataan yang terjadi di masyarakat menengah kebawah adalah tidak adanya akses untuk modal usaha yang memadai untuk memulai atau meningkatkan perkembangan usahanya tersebut, sehingga produktivitas usahanya menjadi tidak meningkat. Masyarakat menengah kebawah sangat memerlukan akses permodalan berupa pinjaman atau kredit, salah satunya kredit usaha yang dikeluarkan oleh Koperasi. Dengan adanya permodalan usaha melalui koperasi, masyarakat terlebih dahulu diharuskan untuk aktif dan mengerti perihal keuangan sebagai pengguna modal nantinya, sasaran utamanya adalah agar kedepannya Usaha Kecil dan Menengah (UKM) bisa membawa dampak yang baik bagi perekonomian Indonesia.

Menurut penelitian yang dilakukan oleh Yusuf (2017), semakin besar jumlah kredit usaha yang diperoleh oleh UKM di Kota Bangka, maka akan semakin tinggi tingkat pendapatan yang diperoleh UKM. Namun disisi lain menurut penelitian Irman (2018) 
menyatakan bahwa semakin banyak modal pinjaman yang diambil oleh UKM di Kota Bandung, maka penghasilan UKM juga akan mengalami peningkatan.

Tingkat pendidikan dapat mempengaruhi kemampuan masyarakat dalam mempertimbangkan dan mengambil keputusan untuk menentukan jumlah kredit yang diambil untuk menambah biaya hidup, maka dengan kemampuan yang dimiliki, masyarakat mempunyai kemauan untuk mengambil kredit yang dibutuhkan (Rajan.2003). Menurut Eko (2009) dalam penelitiannya menyatakan tingkat pendidikan adalah faktor yang mempengaruhi permintaan KUR dimana semakin tinggi tingkat pendidikan seseorang, maka usaha yang dijalankan dalam jumlah yang besar sehingga mengakibatkan perlunya pinjaman modal untuk perkembangan dan perluasan usahanya. Menurut Todaro (2000) bahwa seseorang dapat meningkatkan penghasilan melalui peningkatan pendidikan, setiap tambahan satu tahun sekolah berarti disatu pihak meningkatkan kemampuan kerja dan tingkat penghasilan seseorang. Karena dalam pengalokasian sumber daya manusia akan diserap oleh lapangan kerja (Fadhilah Rahmawati, dkk, 2004).

Faktor lainnya yang mempengaruhi efektivitas penggunaan kredit adalah jangka waktu kredit. Dalam jurnal ekonomi Undiksha (2012) disebutkan bahwa jangka waktu kredit yang lama menjadi faktor penyebab rendahnya tingkat pengembalian kredit. Kurangnya motivasi menjadi faktor utama hal tersebut. Dalam penelitian yang dilakukan oleh Musmini
(2013) pelaku UKM di Kota Denpasar memiliki motivasi yang rendah dalam hal pengembalian kredit jangka panjang, akibatnya penggunaan kredit menjadi tidak efektif. Sebagian pelaku UKM berpendapat bahwa semakin lama jangka waktu kredit maka semakin lama mereka memiliki waktu untuk membayar, sehingga motivasi dalam pengembalian menjadi sangat rendah.

Lama pembukaan usaha dapat mempengaruhi tingkat pendapatan, lamanya seorang pelaku usaha atau bisnis menekuni bidang usahanya akan mempengaruhi produktivitasnya (kemampuan/keahliannya), sehingga dapat menambah efisiensi dan mampu menekan biaya produksi lebih kecil dari pada hasil pendapatan. Semakin lama menekuni bidang usaha perdagangan akan makin meningkatkan pengetahuan tentang selera ataupun perilaku konsumen. Keterampilan berdagang makin bertambah dan semakin banyak pula relasi bisnis maupun pelanggan yang berhasil di jaring (Wicaksono, 2011). Keahlian keusahawaan merupakan kemampuan yang dimiliki seseorang untuk mengorganisasikan dan menggunakan faktorfaktor lain dalam kegiatan memproduksi barang dan jasa yang diperlukan masyarakat (Sukirno, 1994).

Berdasarkan fenomena dan kajian teoritis serta empiris pada latar belakang tersebut, maka penelitian ini layak dilakukan untuk mengetahui seberapa besar tingkat efektivitas penggunaan kredit usaha terhadap produktivitas UKM dan pendapatan UKM di Kelurahan Padangsambian. 
Penelitian ini memiliki tujuan antara lain (1) Untuk mengetahui pengaruh efektivitas penggunaan kredit terhadap produktivitas UKM di Kelurahan Padangsambian. (2) Untuk mengetahui pengaruh efektivitas penggunaan kredit terhadap pendapatan UKM di di Kelurahan Padangsambian. (3) Untuk mengetahui ada atau tidaknya pengaruh tidak langsung efektivitas penggunaan kredit terhadap Pendapatan UKM di Kelurahan Padangsambian melalui produktivitas UKM di di Kelurahan Padangsambian.

\section{TINJAUAN PUSTAKA}

\section{Efektivitas}

Efektivitas merupakan kemampuan dalam melaksanakan tugas dan fungsi dalam suatu organisasi atau sejenisnya tanpa adanya tekanan atau ketegangan diantara pelaksanaannya (Kurniawan, 2005). Suatu organisasi secara keseluruhan dalam kaitannya dengan efektivitas adalah mencapai tujuan organisasi. Jika setiap individu berperilaku atau bekerja efektif dalam mencapai tujuannya, maka fungsi dari organisasi akan menjadi efektif. Efektivitas berbeda dengan efesiensi. Efesiensi adalah pengorbanan untuk mencapai tujuan. Semakin kecil pengorbanannya dalam mencapai tujuan, maka dikatakan semakin efesiensi. Sedangkan Efektivitas adalah ukuran sejauh mana tujuan (organisasi) dapat dicapai (Sigit, 2003).

\section{Produktivitas}

Konsep produktivitas pada dasarnya dapat
Hipotesis dalam penelitian ini yaitu: (1) Efektivitas penggunaan kredit berpengaruh positif dan signifikan terhadap produktivitas UKM di di Kelurahan Padangsambian. (2) Efektivitas penggunaan kredit berpengaruh positif dan signifikan terhadap pendapatan UKM di di Kelurahan Padangsambian. (3) Efektivitas penggunaan kredit berpengaruh secara tidak langsung terhadap pendapatan UKM di di Kelurahan Padangsambian melalui produktivitas UKM.

dilihat dari dua dimensi, yaitu dimensi individu dan dimensi organisasi. Pengkajian masalah produktivitas dari dimensi individu tidak lain melihat produktivitas terutama dalam hubungannya dengan karakteristikkarakteristik kepribadian individu. Dalam konteks ini esensi pengertian produktivitas adalah sikap mental yang selalu mempunyai pandangan bahwa mutu kehidupan hari ini harus lebih baik dari hari kemarin, dan hari esok harus lebih baik dari hari ini (Kusnendi, 2003:8.4).

\section{METODE}

Metode penelitian yang digunakan didalam penelitian ini menggunakan metode kuantitatif. Data primer diperoleh dari responden menggunakan kuisioner yang disebarkan melalui email dan dibagikan secara langsung, untuk kemudian di isi oleh masingmasing responden. Populasi dalam penelitian ini terdiri dari 1025 pemilik usaha yang melakukan peminjaman kredit usaha di koperasi yang berada di Kelurahan 
Padangsambian dari tahun 2015 sampai tahun 2019. Teknik pengambilan sampel dalam penelitian menggunakan stratified random sampling. Dengan tingkat kesalahan 10 persen, yang kemudian dihitung menggunakan rumus slovin maka akan didapat sampel yang diteliti berjumlah 100 sampel. selanjutnya, metode pengambilan sampel di tiap desa dilakukan dengan menggunakan metode stratified random sampling. Menurut Sugiyono (2010) stratified random sampling adalah teknik yang digunakan bila populasi mempunyai anggota/unsur yang tidak homogen dan berstrata secara proporsional.

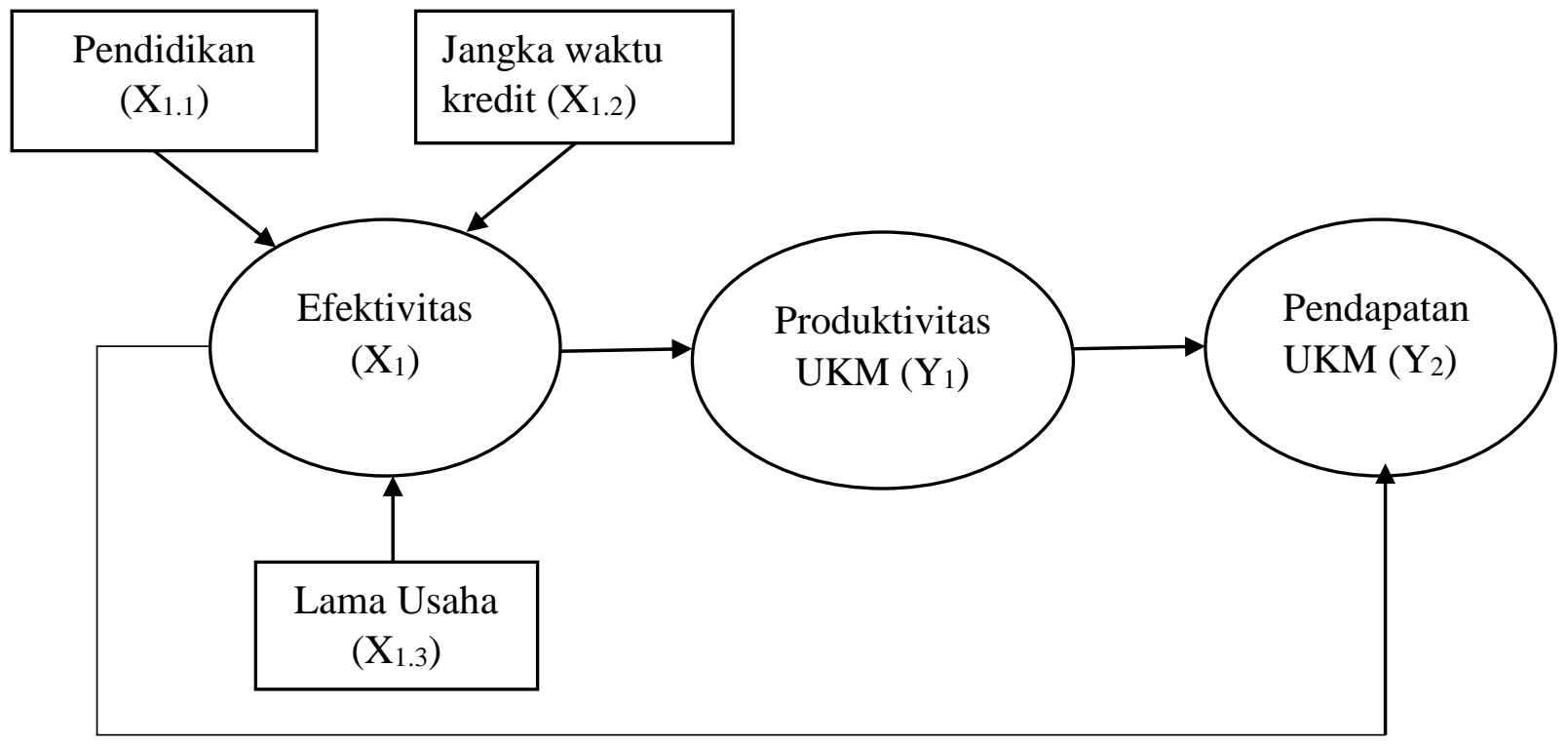

\section{Gambar 1}

Konsep pengaruh penelitian efektivitas penggunaan kredit usaha kecil dan menengah kelurahan Padangsambian, Kecamatan Denpasar Barat, Provinsi Bali.

Sedangkan teknik analisis data yang dipakai dalam penelitian ini untuk mengetahui pengaruh variabel yang diteliti adalah dengan menggunakan teknik Partial Least Square (PLS) dengan menggunakan software Smart PLS 3.0.
Variabel dalam penelitian ini dapat diidentifikasi sebagai berikut: Variabel dependen yang digunakan dalam penelitian ini adalah variabel Pendapatan UKM di Kelurahan Padangsambian. Sedangkan variabel independen yang digunakan dalam penelitian ini adalah variabel Efektivitas penggunaan kredit. Variabel intervening yang digunakan dalam penelitian ini adalah Produktivitas UKM. Adapun konsep dan kerangka berfikir penelitian ini, seperti di jelaskan pada Gambar 1. 
model melalui telaah terhadap berbagai kriteria goodness of fit. Berikut ini hasil analisa goodness of fit indeks dari hasil uji full model disajikan pada Tabel 3.

Tabel 3

Goodness of Fit Index

\begin{tabular}{c|c|c|c}
\hline $\begin{array}{c}\text { Goodness of Fit Measure } \\
\text { Nilai Kritis }\end{array}$ & (Cut of Value) & $\begin{array}{c}\text { Hasil } \\
\text { Analisis }\end{array}$ & $\begin{array}{c}\text { Evaluasi } \\
\text { Model }\end{array}$ \\
\hline Chi Square $(\lambda 2)$ & Diharapkan & 8,397 & marginal \\
& kecil $\leq 3,841$ & & \\
Significance Probability $(p)$ & $\geq 0,05$ & 0.004 & marginal \\
RMSEA & $\leq 0,08$ & 0,221 & Kurang baik \\
GFI & $\geq 0,90$ & 0.985 & baik \\
AGFI & $\geq 0,90$ & 0,574 & Baik \\
CMIN/DF & $\leq 2,00$ & 1 & Baik \\
CFI & $\geq 0,94$ & 0,989 & Baik \\
\hline
\end{tabular}

Sumber: hasil pengolahan data

Hasil selengkapnya pengujian kriteria layak tidaknya model (goodness of fit index) tahap akhir dapat dilihat pada Tabel 3 Berdasarkan parameter nilai goodness of fit index, hanya nilai RMSEA yang kurang baik, sehingga dapat dikatakan bahwa model analisa secara keseluruhan sudah fit dan ada kesesuaian antara model dan data.

Evaluasi terhadap goodness of fit yang dilakukan dengan melihat besarnya $R^{2}$ dapat disajikan pada Tabel 4 sebagai berikut:

Tabel 4

\section{Square Multiple Correlations}

\begin{tabular}{l|l}
\hline Variabel & R Square \\
\hline Produktivitas UKM $\left(\mathrm{Y}_{1}\right)$ & 0,635 \\
Pendapatan UKM $\left(\mathrm{Y}_{2}\right)$ & 0,754 \\
\hline
\end{tabular}

Sumber: hasil pengolahan data

Berdasarkan Tabel 4, dapat disimpulkan bahwa nilai $\mathrm{R}$ square sebesar 0.635 untuk Produktivitas UKM ( $\left.\mathrm{Y}_{1}\right)$, berarti model regresi memiliki goodness-fit yang baik dimana Produktivitas UKM dapat dijelaskan oleh variabel Pendapatan UKM $\left(\mathrm{Y}_{2}\right)$ sebesar 63,50\% dan 36,50 \% dijelaskan oleh variabel lain yang tidak diteliti dalam model ini. Nilai R square Pendapatan UKM $\left(\mathrm{Y}_{2}\right)$ sebesar 0,754 yang berarti model regresi memiliki goodness-fit yang baik dimana variabel pendapatan dapat dijelaskan oleh variabel produktivitas sebesar 
$75,40 \%$ dan $24,60 \%$ dijelaskan oleh variabel lain yang tidak diteliti dalam model ini.

Berdasarkan Tabel 4 dapat diketahui bahwa efektivitas penggunaan kredit, produktivitas UKM dan pendapatan UKM baik dan dapat dirpercaya sebagai alat pengumpulan data dalam penelitian, karena memiliki discriminant validity yang lebih besar dari 0.60 untuk Average Variance Extracted (AVE) dan composite reliability serta cronbach alpa diatas 0.8. Pengujian kepada model struktural bisa dilakukan dengan melihat nilai Rsquare atau uji goodness fit model. Evaluasi terhadap model struktural (Inner model) berkaitan dengan pengujian hubungan antar variabel laten yang sebelumnya telah dihipotesiskan. Kebaikan model ditunjukkan dengan menggunakan nilai R-Square (R2) dan nilai Q-Square(Q2). RSquare menjelaskan seberapa besar variabel eksogen yang dihipotesiskan dalam persamaan mampu menerangkan variabel endogen. Model pengujian R-square dapat dilihat pada Tabel 4

Tabel 5

Hasil Pengujian Path Coefficients (Mean, STDEV, T-Values)

\begin{tabular}{lllllll}
\hline & $\begin{array}{l}\text { Original } \\
\text { Sample } \\
(\mathrm{O})\end{array}$ & $\begin{array}{l}\text { Sample } \\
\text { Mean } \\
(\mathrm{M})\end{array}$ & $\begin{array}{l}\text { Standar } \\
\text { Deviation } \\
(\mathrm{STDEV})\end{array}$ & $\begin{array}{l}\text { T Statistic } \\
(\mid \mathrm{O} / \text { STERR })\end{array}$ & $\begin{array}{l}\text { Standar } \\
\text { Error } \\
(\text { STERR })\end{array}$ & Ket \\
\hline $\begin{array}{l}\text { Efektivitas } \rightarrow> \\
\text { UKM }\end{array}$ & 0,812 & 0,733 & 0,032 & 17,265 & 0,031 & Sig \\
$\begin{array}{l}\text { Efektivitas-> Produktivitas } \\
\text { UKM }\end{array}$ & 0,356 & 0,246 & 0,121 & 2,923 & 0,122 & Sig \\
$\begin{array}{l}\text { Produktivitas } \\
\text { Pendapatan UKM }\end{array}$ & 0,192 & 0,120 & 0,191 & 2,183 & 0,068 & Sig \\
\hline
\end{tabular}

Berdasarkan data pada Tabel 5, ditampilkan hasil uji Path Coefficients dengan menggunakan PLS, yang menunjukkan terdapat tiga hubungan antar variabel yaitu efektivitas dengan pendapatan, efektivitas dengan produktivitas, dan produktivitas dengan pendapatan dinyatakan positif dan signifikan karena hasil pengujian diketahui nilai t-statistik lebih besar dari 1,96.

Hasil penelitian pengaruh tidak langsung dengan melihat besar pengaruh variabel bebas efektivitas penggunaan kredit $\left(\mathrm{X}_{1}\right)$ terhadap variabel terikat pendapatan UKM melalui variabel intervening produktivitas UKM yaitu sebesar 0.837. Pengaruh total menunjukkan keseluruhan nilai pengaruh variabel secara langsung maupun tidak langsung. Berdasarkan hasil analisis pengujian pengaruh total, menunjukkan bahwa yaitu efektivitas penggunaan kredit berpengaruh positif dan signifikan terhadap pendapatan UKM, efektivitas penggunaan kredit berpengaruh 
positif dan signifikan terhadap produktivitas UKM dan produktivitas UKM berpengaruh positif dan signifikan terhadap pendapatan UKM.

Hasil penelitian ini menunjukkan bahwa efektivitas penggunaan kredit UKM di Kelurahan Padangsambian berpengaruh positif dan signifikan terhadap produktivitas UKM. Hal ini berarti apabila tingkat efektivitas penggunaan kredit meningkat maka produktivitas UKM juga meningkat, begitu juga sebaliknya. Penggunaan kredit UKM tersebut dikatakan sudah mampu memberikan berkontribusi dalam meningkatkan kegiatan perekonomian melalui UKM di Kelurahan Padangsambian.

Perkembangan UKM di Kelurahan Padangsambian merupakan tujuan bersama dari peningkatan profesionalitan dan efektivitas penggunaan kredit UKM yang ada di Kelurahan Padangsambian untuk membantu dan memberikan kontribusi dalam meningkatkan perekonomian, sehingga penggunaan modal yang diperoleh menjadi lebih efektif. Menurut Agus (2016) efektivitas adalah merupakan kesinambungan tujuan yang telah ditetapkan oleh lembaga Pelaksana keuangan dengan debitur, yang bertujuan memberikan manfaat bagi pengusahapengusaha mikro (UKM) dalam mengembangkan usahanya yang ditunjukan dengan meningkatnya produktivitas dan pendapatan serta adanya timbal balik yang diberikan oleh kreditur kepada debitur berupa pembayaran angsuran dengan tepat waktu.

\section{SIMPULAN}

Dari hasil analisis dan pembahasan dari isi penelitian sebagaimana dijelaskan terlebih dahulu, maka kesimpulan yang dapat disampaikan oleh peneliti adalah bahwa Efektivitas penggunaan kredit usaha $\left(\mathrm{X}_{1}\right)$ dengan menggunakan 2 indikator dari 3 indikator yaitu tingkat pendidikan, jangka waktu usaha, dan lama usaha berpengaruh positif dan signifikan terhadap produktivitas UKM $\left(\mathrm{Y}_{1}\right)$ di Kelurahan Padangsambian. Produktivitas UKM $\left(\mathrm{Y}_{1}\right)$ berpengaruh positif dan signifikan terhadap pendapatan UKM $\left(\mathrm{Y}_{2}\right)$ di Kelurahan Padangsambian. Efektivitas penggunaan kredit usaha $\left(\mathrm{X}_{1}\right)$ berpengaruh positif dan signifikan terhadap pendapatan $\mathrm{UKM}\left(\mathrm{Y}_{2}\right)$ melalui produktivitas UKM $\left(\mathrm{Y}_{1}\right)$ di Kelurahan Padangsambian.

Segala bentuk kegiatan usaha kecil menengah (UKM) di Kelurahan Padangsambian perlu diiringi dengan pemberian sosisalisai guna untuk mencegah kelalaian serta penyalahgunaan kredit usaha, sehingga upaya yang harusnya dilakukan oleh pemerintah adalah untuk mengangkat dan meningkatkan mutu perekonomian masyarakat di Kelurahan Padangsambian dengan melakukan kegiatan pembinaan dan sosialisasi yang berkaitan dengan manajemen keuangan, pelatihan usaha untuk tercapainya realisasi penggunaan kredit yang efektif, sehingga penggunaan kredit yang sifatnya konsumtif dapat dikurangi. 
https://ejournal.warmadewa.ac.id/index.php/wicaksana

\section{DAFTAR PUSTAKA}

Agus, Suhendra, 2013. Faktor-faktor yang mempengaruhi produktivitas usaha tani kopi di Kecamatan Bukit Tinggi, Sumatra Utara.

Akmal, Yori, 2006. Analisis Faktor-Faktor Yang Mempengaruhi Produktivitas Tenaga Kerja Industri Kecil Kerupuk Sanjai di Kota Bukittinggi, Fakultas Pertanian Institut Pertanian Bogor.

Artayasa, Komang Ary, 2011. "persepsi masyarakat miskin terhadap efektivitas penggunaan modal bantuan rumah tangga miskin, di Kecamatan Tabanan"

Asmi, Suryani 2008 “Analisis pengaruh tenaga kerja, lama usaha, jumlah modal terhadap peningkatan produksi usaha tani bawang putih di Desa Sukaharjo”

Atmaja, A. W. K. 2010. Hubungan Antara Persepsi Terhadap Pelatihan Kerja dengan Motivasi Kerja Pegawai Negeri Sipil di kantor Kecamatan Genuk Kota Semarang.

Atmanti, Rismawan, 2005. "efektivitas dan dampak program community based development (cbd)-bali sejahtera dalam peningkatan kesempatan kerja dan investasi di kabupaten Tabanan".

Bank Indonesia 2015 Pengertian UKM menurut Negara Indonesia dan Negara Asing

Basu, Sucita Dewa, 2005. "strategi peningkatan kinerja pekerja pada perusahaan konstruksi Hutama Karya melalui pendekatan budaya organisasi".

BPS. 2019. Bali Dalam Angka tahun 20142019. Badan Pusat Statistik. Bali

Dinas Koperasi dan UMKM Provinsi Bali 2019. "Data jumlah UKM Provinsi Bali tahun 2014-2019”.

Erina, Winata, 2009. "Peran masa pendidikan dalam memediasi pengaruh faktor ekonomi, sosial dan demografi”".

Fitri, Kumala Sari dkk, 2011. "persepsi pelaku UKM terhadap efektivitas pelaksanaan program nasional pemberdayaan masyarakat mandiri perkotaan (pnpmmp) : studi kasus UKM Kabupaten Gianyar"

Hair, J.F. et all, (1998), Multivariate Data Analysis, Prentice Hall, New Jersey.

Hair, Black, Babin, Anderson, Tatham (2006), Multivariate Data Analysis, $6^{\text {th }}$ edition, Pearson Prentice Hall, New Jersey.

Husein, Umar. 2011. Metode Penelitian Untuk Skripsi dan Tesis Bisnis Edisi 11. Jakarta: PT Raja Grafindo Persada

Ida Bagus Mantra . 2003.Demografi Umum. Edisi ke-2. Yogyakarta: Pustaka Belajar.

Jurnal Ekonomi Undiksha, 2012. "Jangka waktu kredit dan penyebab keterlambatan pembayaran usaha kecil dan menengah" Singaraja. 
Kirana, Setyadewi, 2011. "Efektivitas dan dampak program community based development (cbd)-bali sejahtera dalam peningkatan kesempatan kerja dan pendapatan rumah tangga miskin di Kabupaten Klungkung”

Kuncoro, Haryo. 2007, Fenomena Flypaper Effect pada Kinerja Keuangan Daerah Kota dan Kabupaten di Indonesia, Simposium Nasional Akuntansi $X$, Makassar.

Mulyadi. 2009. Auditing. Jakarta: Salemba Empat Umar, Husein.2007. Metode Penelitian untuk Skripsi dan Tesis Bisnis. Jakarta : PT gramedia Pustaka.

Muliani, Dwi, 2012, "analisis daya beli, kredit, dan jam kerja terhadap peningkatan perekonomian pedagang "canang"di Pasar Ketapean, Kesiman, Denpasar Timur."

Mulyanto.2002."Potensi Pajak Daerah dan Retribusi Daerah di Kawasan Subosuka Wonosaren Propinsi Jawa Tengah (The Potential of Local Government Revenue : A Case Study in Subosuka Wonosaren District, Central Java Provincies)". Economics Faculty Sebelas Maret University. Surakarta.

Murdiana, Putu, 2008. "efisiensi penggunaan kredit rakyat untuk usaha peternakan ayam ras pedaging di kabupaten tabanan"
Muriani, Desak Ayu, 2011. "Pengaruh kinerja kredit terhadap alokasi pertumbuhan ekonomi pemerintah kabupaten/kota se-provinsi bali".

Musmini, Sri Ayu, 2013. “Analisis faktorfaktor yang mempengaruhi motivasi pengembalian kredit dan produktivitas usaha kecil dan menengah bimbingan dinas koperasi dan UKM Kecamatan Denpasar Timur".

Nata Wirawan, I Gusti Putu. 2002. "Cara Mudah Memahami Statistik 2 (Statistik Inferensia) untuk ekonomi dan bisnis", Denpasar : edisi kedua, Keraras Emas.

Novianti, Putri 2009. Faktor-faktor yang mempengaruhi produktifitas pertumbuhan usaha mikro, kecil, dan menengah Kecamatan Kuta Selatan.

Nugroho, Riant. 2009. Public Policy Teori Kebijakan (Analisis Kebijakan, Proses Kebijakan Perumusan Implementasi, Evaluasi, Revisi Risk Management Dalam Kebijakan Publik, Kebijakan Sebagai The Fifth Estate, Metode Penelitian Kebijakan). Jakarta: PT. Elex Media Komputindo.

Rusman, Setyabudi, 2013. "analisis faktorfaktor yang berpengaruh terhadap pendapatan dan kredit rumah tangga pekerja kapal pesiar asal kota denpasar" 
Saputra, Artana 2007. “analisis pengaruh faktor internal dan eksternal terhadap jumlah kredit dan

$$
\text { dampaknya terhadap ketimpangan }
$$

pendapatan antar pedagang pasar".
Semara, Adiputra, 2013. “Analisis faktor yang mempengaruhi peningkatan jumlah

produksi usaha pengolahan tahu dan tempe di Kecamatan Denpasar Barat. 